bu życia. Autorka stwierdza na podstawie własnych badań, że pobyt młodzieży w placówkach resocjalizacyjnych nie gwarantuje skutecznych oddziaływań.

Rozwiązania profilaktyczne i resocjalizacyjne w naturalnym środowisku nieletniego proponuje Robert Opora. W oparciu o ekologiczny model profilaktyki uzależnień wskazuje na możliwość kształtowania odporności psychicznej u młodzieży przez interdyscyplinarny zespół specjalistów.

Według Małgorzaty Michel alternatywą dla instytucjonalnych metod profilaktyki i resocjalizacji dzieci i młodzieży jest streetworking, czyli tzw. pedagogika podwórkowa. Praktyczna działalność wychowawcza jest tu prowadzona bezpośrednio na ulicy, podwórku, dając możliwość dotarcia, nawiązania kontaktu, zrozumienia i udzielenia pomocy dzieciom najbardziej zaniedbanym i zagrożonym patologią.

Trzecią część i jednocześnie całą prezentowaną pracę zamyka artykuł Krzysztofa Biela traktujący o resocjalizacji specyficznej grupy młodzieży niedostosowanej społecznie, mianowicie dziewcząt przejawiających zachowania agresywne. Poza teoretyczną analizą zjawiska agresji dziewcząt, autor przedstawia także rozmiary zjawiska według policyjnych statystyk oraz możliwości praktycznych oddziaływań resocjalizacyjnych.

Po lekturze recenzowanej publikacji można stwierdzić, że niewątpliwie spełniony został zamysł redaktorek wzbogacenia wiedzy czytelnika na temat związków teorii i praktyki pedagogicznej. Jednak ocenę czy wiedza ta wpłynęła na jednostkowe postrzeganie rzeczywistości wychowawczej należy pozostawić indywidualnemu czytelnikowi.

Anna Knocińska

\title{
Kultura zabawy, pod redakcją Tadeusza Palecznego, Ryszarda Kantora, Magdaleny Banaszkiewicz, Wydawnictwo Uniwersytetu Jagiellońskiego, Kraków 2012, ss. 242
}

Trudno sobie wyobrazić życie dzieci i dorosłych bez zabawy. Stanowi ona istotny element ludzkiej egzystencji. Zabawa do niedawna stanowiła mało interesujący temat badawczy, dla wielu była wręcz tematem niepoważnym. Dopiero w ostatnich kilku dziesięcioleciach problematyka zabawy została nobilitowana do ważnych i cennych problemów i stała się dla wielu naukowców - reprezentujących różne dziedziny naukowe poważnym zagadnieniem naukowym ${ }^{1}$. Interdyscyplinarność badań nad zabawą może

${ }^{1}$ Por. m.in. J. Bujak, Zabawki w Europie, Kraków 1988; J. Cieślikowski, Wielka zabawa, Warszawa 1985; K. Kabacińska, Zabawy i zabawki dziecięce w osiemnastowiecznej Polsce, Poznań 2007; Dawne zabawy dziecięce, pod red. D. Żołądź-Strzelczyk, K. Kabacińskiej, Kielce-Warszawa 2008; Dawne $i$ współczesne zabawki dziecięce, pod red. D. Żołądź-Strzelczyk, K. Kabacińskiej, Poznań 2010; A. Brzezińska, Aktywność zabawowa i jej znaczenie dla rozwoju dziecka, w: Nieobecne dyskursy, cz. VI, pod red. Z. Kwiecińskiego, Toruń 2000; R. Caillois, Gry i ludzie, Warszawa 1997; J. Grad, Zabawa - analiza pojęć i koncepcji, „Zabawy i Zabawki” 1997, nr 1-2; J. Huizinga, Homo ludens, Warszawa 1988; U. Kaczmarek, Pedagogika zabawy, „Zabawy i Zabawki" 1997, nr 4; A. Kamiński, Aktywizacja i uspołecznienie uczniów w szkole podstawowej, Warsza- 
świadczyć o dostrzeżeniu istotnego znaczeniu zabawy zarówno dla rozwoju i funkcjonowania jednostki (dziecka i dorosłego), jak i dla społeczeństwa. Z jednej strony zabawa była i jest odzwierciedleniem sytuacji społecznej, kulturowej i politycznej (np. zabawy opisane przez Łukasza Gołębiowskiego i wydane w roku 1831 w zbiorze Gry i zabawy różnych stanów w kraju całym, lub niektórych tylko prowincjach...), z drugiej wyrasta z wewnętrznej potrzeby człowieka do wchodzenia w różne role społeczne i zawodowe. Trudno jest stworzyć jedną, definicję zabawy, tak jak niemożliwe jest ujęcie problematyki zabawy w jednym opracowaniu.

Wieloaspektowość zabawy, jej uniwersalizm i ponadczasowość są, co już zostało podkreślone, coraz częstszym tematem badawczym. Jedyne polskie czasopismo poświęcone problematyce zabaw i zabawek ukazuje się od 1997 r. w Muzeum Zabawek i Zabawy w Kielcach ${ }^{2}$. Jego redaktorem naczelnym jest prof. zw. dr hab. Ryszard Kantor (Uniwersytet Jagielloński w Krakowie). Na łamach „Zabaw i Zabawek” można znaleźć teksty dotyczące różnorodnych zagadnień teoretycznych i praktycznych związanych z zabawą i ludycznością. Klasykami korzystającymi z dorobku wielu dziedzin nad rolą i istotą zabawy są w Polsce, m.in.: Ryszard Kantor, Tadeusz Paleczny, Bogusław Sułkowski, Wincenty Okoń, Dorota Żołądź-Strzelczyk. Każdy z nich - zgodnie z reprezentowaną dziedziną naukową - opisuje problematykę zabaw i zabawek z innej perspektywy. Tematyce zabaw i zabawek poświęcono również konferencje naukowe oraz projekty badawcze.

Udaną próbą scharakteryzowania fenomenu zabawy z punktu widzenia socjologicznego i kulturowego jest książka Kultura zabawy pod redakcją Tadeusza Palecznego, Ryszarda Kantora i Magdaleny Banaszkiewicz, wydana jako kolejny tom serii Varia Culturalia przez Wydawnictwo Uniwersytetu Jagiellońskiego w Krakowie. W publikacji tej głos zabrali nie tylko nestorzy badań nad zabawą, ale także młodzi naukowcy, dla których „różne fenomeny kulturowe związane z tą szeroką sferą aktywności człowieka” (s. 12-13.) stały się cennym tematem badawczym. Większość autorów tekstów jest pracownikami Uniwersytetu Jagiellońskiego, jednak do współpracy zaproszono także badaczy z innych ośrodków naukowych, m.in. z Uniwersytetu Warszawskiego, Uniwersytetu Śląskiego, Uniwersytetu Opolskiego, Uniwersytetu Kardynała Stefana Wyszyńskiego w Warszawie, Akademii Ignatianum w Krakowie. Kultura zabawy zdaje się nawiązywać do wcześniejszej publikacji wydanej we wspomnianej serii Wąz w raju. Zabawa w spo-

\footnotetext{
wa 1966; T. Lewińska, Kolorowy świat zabawek. Zabawki ludowe w Polsce, Kielce 1995; W. Okoń, Zabawa a rzeczywistość, Warszawa 1987; T. Paleczny, Społeczne podłoże zabawy, „Zabawy i Zabawki” 1997, nr 1-2; J. Wygotski, Zabawa i jej rola $w$ rozwoju psychicznym dziecka, w: Dziecko $w$ zabawie i świecie języka, pod red. A. Brzezińskiej, T. Czuba, G. Lutomskiego, B. Smykowskiego, Warszawa 1995; A. Zadrożyńska, Homo faber i homo ludens, Warszawa 1983; A. Zadrożyńska, Świętowania polskie, Warszawa 2002; R. Zięzio, Wokót naczelnej zasady funkcjonalnej w zachowaniach ludycznych, „Zabawy i Zabawki” 1997, nr 3; F. Znaniecki, Ludzie teraźniejsi a cywilizacja przyszłości, Warszawa 1974;

2 ttp://www.muzeumzabawek.eu/mziz/index.php?option=com_content\&task=blogcategory\&id=79\&Itemid=127, z dnia 03.01.2014.
} 
teczeństwie konsumpcyjnym pod redakcją Ryszarda Kantora, Tadeusza Palecznego i Magdaleny Banaszkiewicz ${ }^{3}$. Obie pozycje wzajemnie się uzupełniają i dopełniają.

Przedstawiona w publikacji problematyka dotyczy szerokiego znaczenia zabawy, szczególnie form czynnego i biernego uczestnictwa w kulturze przez udział m.in. w różnego typu przedstawieniach (np. teatru alternatywnego), w spektaklach karnawału, w telewizyjnych programach itp. Układ artykułów jest jasny i logiczny - od tekstów ogólnych, długoletnich badaczy, poruszających problematykę z perspektywy teoriopoznawczej, przez analizę kulturowego znaczenia uczestnictwa w zabawie (teatr, maska), po szczegółowe zagadnienia dotyczące wybranych aspektów zabawy i zabawek - od gier wideo począwszy, na roli lalki we współczesnym społeczeństwie konsumpcyjnym skończywszy.

W oryginalnym wstępie, a właściwie tekście wprowadzającym, autorka, Magdalena Banaszkiewicz, przedstawiła klasyczne teorie zabawy - m.in. Arystotelesa, Platona, Johna Huizingi i Floriana Znanieckiego, które mniej lub bardziej literalnie stanowią tło rozważań większości tekstów oraz dokonała krótkiej prezentacji podejmowanych problemów.

Pierwsza część książki stanowi wprowadzenie teoretyczne do tematyki zabawy. Tadeusz Paleczny w tekście Transgresyjne formy zabawy w świecie ponadczasowym, próbuje odpowiedzieć na pytanie „o granice zabawy i jej związku z kulturą rdzenną, masową i popularną, dominującą" (s. 23) oraz udowodnić, że subkultury emo czy gothic są przejawem transgresji w kulturze. Ryszard Kantor poddał refleksji kulturę konsumpcji zabawy, zwracając uwagę na to, że „społeczeństwo konsumpcyjne jest to społeczeństwo hedonistyczne, choć oczywiście nie wszyscy jego członkowie mają świadomość, że prezentują postawę hedonistyczną, ba, wielu postawę taką wręcz odrzuca" (s. 49). Trzeci tekst, podobnie jak dwa poprzednie, podejmuje problematykę różnicy między zabawą a rozrywką. Paweł Cieślarek, odwołując się do rozważań Christophera Lascha i Neila Postmana, zadał pytanie ,w jaki sposób [...] współczesne media, które pozostają w służbie przemysłu rozrywkowego, komunikują założenia światopoglądowe, wpisujące się w [...] rozważania na temat charakteru współczesnej kultury" (s. 58).

Kolejne trzy artykuły łączy związek zabawy i sztuki. Krzysztof Wałczyk, z prawdziwą erudycją, odwołując się do wielu różnych tekstów kultury - w tym także religijnych i uściślając teorię Johana Huizingi, próbuje pokazać istotę funkcji terapeutycznej zabawy. Ten ważny poznawczo tekst, byłby - z punktu widzenia a pedagoga - bogatszy i pełniejszy, gdyby Autor odwołał się w nim także do koncepcji psychologiczno-pedagogicznych odnoszących się do terapeutycznej funkcji zabawy. Związek zabawy i teatru alternatywnego omówiła Lilianna Dorak-Wojakowska, odwołując się do współczesnych form teatru karnawałowego w Polsce (Teatr Strefa Ciszy, Teatr Wiejski Węgajty). Trafnie zauważyła, że „Stopniowe przechodzenie karnawału od fazy zabawy do fazy najpierw widowiskowej, a potem święta wskazuje na jego świąteczny charakter, który determinuje pełnione funkcje. Podczas gdy zabawa określa treść konkretnych praktyk, widowisko staje się

\footnotetext{
3 Wą̇̇ w raju. Zabawa w społeczeństwie konsumpcyjnym, pod red. R. Kantora, T. Palecznego, M. Banaszkiewicz, Wydawnictwo Uniwersytetu Jagiellońskiego, Kraków 2011.
} 
często sposobem ich uzewnętrznienia” (s. 94). Z tymi rozważaniami koresponduje następny tekst autorstwa Marzeny Maciulewicz „Miejsce i znaczenie maski we współczesnych obchodach karnawałowych na przykładzie Rijeki”. Autorka, przedstawiając interesujące dla polskiego odbiorcy, chorwackie obyczaje karnawałowe, zaobserwowała „kilka charakterystycznych tendencji zmiany tożsamości, towarzyszących zabawie karnawałowej” (s. 110). Natomiast Magdalena Szalbot wpisała się w omawianą problematykę zabawy, odwołując się do znanej w literaturze przedmiotu koncepcji traktowania opozycyjnie pojęć zabawa-praca. Autorka, stosując metodę wywiadu, przedstawiła wnioski z badań nad występowaniem i obecną postacią zachowań ludycznych w pracy zawodowej. W konkluzji trafnie zauważyła „Rozpatrując zachowania zabawowe towarzyszące pracy jako zjawisko społeczne [...], można dostrzec, że różne formy zabaw pracowniczych nadal są elementem tworzącym i cementującym więzi międzyludzkie oraz integrującym środowiska pracownicze" (s. 137).

Dla pedagoga, szczególnie budzącym ciekawość jest artykuł Edwarda Szkody, w którym poddano analizie kompetencje ludyczne nauczycieli wczesnej edukacji w ich samoocenie. Na podstawie przeprowadzonych badań wśród nauczycieli, Autor zauważył, że zabawa jest nadal postrzegana jako ważna część dziecięcej codzienności. Respondenci podkreślili, że ten istotny - dla wszechstronnego rozwoju dziecka - czas zabawy jest współcześnie zmniejszany przez różne inne formy aktywności. Tekst jest cenny poznawczo, odbiorcę może jednak razić schematyczna - wręcz „myślnikowa” - forma prezentacji wniosków. Zabrakło również konkretnego zdefiniowania zabawy, tym bardziej, że w podjętych w niniejszej książce rozważaniach, jest ona traktowana bardzo szeroko. Mówiąc o zabawie dziecięcej, wydaje się istotne rozróżnienie stricte zabawy od aktu zabawy pojmowanego w szerszym kontekście. Nawiązując do problematyki zabaw młodszych uczestników zabawy, Tomasz Majkowski analizuje współczesne gry wideo, łącząc je z ,systemem etycznym ich użytkowników” (s. 153). Autor dodaje, że „do zrozumienia miejsca elektronicznej rozrywki w kulturze autentyczności istotniejsze od faktu obsadzenia gracza w roli bohatera gromiącego zło ma zezwolenie mu na wybór metody, jaką zło będzie gromić (s. 154).

Przyjęcie roli czytelnika jest trudne jak podjęcie kreacji gracza. Wielu badaczy zabawy - z J. Huizingiem na czele - zastanawiali się, czy czytanie jest formą zabawy. Na pytanie to próbowała znaleźć odpowiedź Małgorzata Gaszyńska-Megiera, według której i „,W świetle ustaleń, jakich dokonano [...] nic nie stoi na przeszkodzie, by postrzegać czytanie jako jedną z odmian zabawy współczesnego człowieka i analizować je w takich kategoriach" (s. 169). To stwierdzenie koresponduje ze znaną w przeszłości formą zabawy, za jaką było uznane czytanie. Autorka przedstawiła niskie wskaźniki czytelnictwa we współczesnej Polsce, podjęła rozważania nad dzisiejszym prestiżem i funkcjami książki. W konkluzji celnie zauważyła „W dalszej perspektywie może się okazać, że przesunięcie książki ze sfery powinności narzucanych normą kulturową do sfery zabawy lub wręcz niewyszukanej rozrywki przyniesie poważne straty społeczne" (s. 182). Po przeczytaniu tego artykułu pojawia się w odbiorcy tęsknota za czasami, kiedy dzieci (także dorośli) spędzali chętnie czas na czytaniu książek, a wejście w „drugą rzeczywistość” - rzeczywistość książki, było wspaniałą przygodą, poruszającą nie tylko wyobraźnię - czego 
przykładem może być rysunek J.P. Norblina z roku 1796-1797 Zaczytana ${ }^{4}$, na którym uboga dziewczynka siedząca przy piecu z zachwytem trzyma na kolanach grubą księgę.

Wydaje się, że dzisiejszym poważnym rywalem książki są media. Karolina Golemo podjęła analizę przeobrażeń zachodzących we włoskiej rozrywce w epoce Berlusconiego. Znaczących zmian należy - zdaniem Autorki - upatrywać w momencie zaistnienia epoki neotelewizji (datowanej od pojawienia się stacji komercyjnych), kiedy to „Motywem przewodnim przestała być odpowiedzialność za widza i misja edukacyjna, a stała się nim chęć zainteresowania jak największej liczby odbiorców" (s. 192).

Ostatnie dwa teksty zostały poświęcone lalkom - zabawkom występującym w kulturze od czasów starożytnych. Małgorzata Wrześniak przedstawiła lalki jako współczesne zabawki świata konsumpcji. Zdaniem Autorki zatraciły one swą pierwotną funkcję, „Babie, zwierzątka Littlest Pet Shop, My Little Pony, Hello służą kolekcjonowaniu, a raczej posiadaniu dla samego posiadania, przedmiot kolekcjonerski powinien bowiem spełniać w założeniu przynajmniej dwie cechy - być estetycznie interesujący [...] i stanowić inwestycję na przyszłość - obu tych cech dość kiczowate zabawki nie spełniają” (s. 210-211). Krytyczna analiza współczesnych lalek może być ciekawym punktem przemyśleń nie tylko dla psychologów, pedagogów czy nauczycieli, ale także dla rodziców, którzy stoją przed nie lada wyborem (nie)kupowania „topowych” zabawek. Z tymi rozważaniami koresponduje ostatni tekst książki Elżbiety Wiącek podejmujący temat roli i znaczenia muzułmańskich lalek. Autorka zauważa „Produkcja coraz to nowszych modeli muzułmańskich lalek i rosnący pobyt to nie tylko jeden z przejawów batalii dżihad kontra McŚwiat. Fenomen ten dowodzi także islamizacji coraz to większych obszarów egzystencji w świecie arabskim" (s. 239).

Lektura książki Kultura zabawy jest zajmująca nie tylko dla badaczy kultury i socjologów. Może się stać cennym doświadczeniem intelektualnym również dla pedagogów, historyków wychowania, a także dla nauczycieli praktyków, którzy odnajdą w tej pozycji wiele interesujących i zrozumiale przedstawionych zjawisk społecznych i kulturowych, w których to zjawiskach aktywnie uczestniczą ich podopieczni.

Walorem publikacji jest niewątpliwie jej edytorska wartość. Pewien niedosyt wywołuje brak zestawień bibliograficznych. Szkoda także, że redaktorzy nie umieścili afiliacji autorów tekstów, na pewno to uzupełnienie wzbogaciłoby niniejszą publikację. Ten spójny tematycznie tom, którego autorzy i redaktorzy reprezentują przede wszystkim szeroko rozumiane nauki o kulturze, mógłby zostać poszerzony o teksty poruszające problematykę zabawy w kontekście historycznym - zarówno teorii zabawy (oprócz Platona, Arystotelesa wielu uczonych dawnych wieków poruszało zagadnienia teoretyczne związane z zabawą), jak i praktyki zabawy. Wiele aspektów zabawy jest ponadczasowych, uniwersalnych i wywodzących się z dawnej teorii i praktyki zabawy i/lub rozrywki.

Niniejsza pozycja wpisuje się w rozwijający się nurt badań nad problematyką zabaw. Zdaje się, że najważniejszymi pytaniami, jakie stawiają sobie - zarówno autorzy, jak i czytelnicy - są te dotyczące granicy między zabawą a rozrywką, granicy szczególnie cienkiej we współczesnej kulturze konsumpcyjnej. Czy w dzisiejszych czasach jest jesz-

\footnotetext{
${ }^{4}$ Por. K. Kabacińska, op. cit., s. 113
} 
cze miejsce na zabawę czy już tylko /aż na rozrywkę? Na ile też coraz częściej jesteśmy bierni podczas zabawy/rozrywki? I w końcu, czy funkcje zabawy nadal są aktualne? Odpowiedzi na te i inne pytania pozostawiają Autorzy uważnym i krytycznym odbiorcom....

Katarzyna Kabacińska-Łuczak

\section{Dorota Żołądź-Strzelczyk, Szkoly w Wielkopolsce - od średniowiecznych po- czątków do reform Komisji Edukacji Narodowej, Wydawnictwo Poznańskie 2010, ss. 324}

Książka pióra wybitnej badaczki specjalizującej się w historii edukacji staropolskiej wpisuje się w krąg dzieł poświęconych dziejom oświaty, myśli i kultury intelektualnej. Autorka rzetelnie wykorzystała dobrze dobrane publikacje. Doceniła dorobek wielu pokoleń uczonych rodzimych i obcych - sięgnęła do klasycznych opracowań oraz uwzględniła najnowsze studia humanistyki polskiej.

Skrupulatnie prezentowane przez Autorkę programy nauczania (często po raz pierwszy wprowadzane do obiegu naukowego) są poznawczo cenne, opatrzone solidnym komentarzem i odniesieniami do przemian kultury umysłowej $\mathrm{w}$ omawianych epokach, dyskusją nad intelektualnymi sądami wybitnych badaczy. Programy i ich wykładnia z pewnością zachęcą badaczy do dalszych studiów komparatystycznych.

Autorka doceniła oświatę protestancką (nie uczynił tego w swej ostatniej książce Stanisław Janeczek - Edukacja oświeceniowa a szkoła tradycyjna. Z dziejów kultury intelektualnej i filozoficznej, Wydawnictwo KUL, Lublin 2008). Dorota Żołądź-Strzelczyk ma świadomość, że w krajach i obszarach, gdzie zwyciężył protestantyzm, kontrolę nad edukacyjnymi przemianami przejęli świeccy - królowie, książęta oraz władze miast. Czołowe placówki luterańskie znacznie szybciej niż katolickie dostosowywały swój profil do oczekiwań społecznych. Przykład stanowią, wspierane organizacyjnie i finansowo przez rady miast, gimnazja w Prusach Królewskich Rzeczypospolitej. Badaczka celnie zauważyła, że na strukturę i program tych szkół wywierała wpływ przede wszystkim kultura protestancka - elitarna, erudycyjna i otwarta na nowe prądy filozoficzne i naukowe, płynące głównie z Niemiec i Niderlandów.

Autorka celnie wyeksponowała podobieństwa i różnice pomiędzy modelem szkół katolickich i protestanckich. Te cenne wątki uwydatniła również w zakończeniu. Można przyznać rację Autorce, że kolegia jezuickie istotnie dawały znaczny zasób wiedzy ogólnej. Adaptując selektywnie cenione dziedzictwo antyku, oddalały się jednak coraz bardziej od osiągnięć świata nauki i kultury. Erudycja nie mogła przecież w pożądanym stopniu ogarnąć rozwijających się i usamodzielniających się dyscyplin. Ratio studiorum z 1599 r. pomijała historię, politykę, prawo i języki nowożytne oraz kunszty rycerskie 